\title{
ARTICLE OPEN \\ Accelerated low water corrosion: the microbial sulfur cycle in microcosm
}

\author{
Martin Smith iD $^{1 *}$, Marjorie Bardiau ${ }^{1}$, Richard Brennan ${ }^{1}$, Heidi Burgess ${ }^{1}$, Jonathan Caplin ${ }^{1}$, Santanu Ray ${ }^{1}$ and Thomas Urios ${ }^{2}$
}

Accelerated low water corrosion is a form of marine steel corrosion caused by bacterial activity. It has a global spread and is potentially responsible for billions of pounds of damage. We have determined in detail both the chemistry of corrosion products and the associated microbiology at a UK site. The corrosion products form a layered structure with iron sulfides at the steel surface and iron oxides and sulfates in contact with water. The iron sulfides are formed by reaction of steel with hydrogen sulfide formed by sulfate-reducing bacteria and are oxidised through a series of sulfur oxidation states by sulfide-oxidising bacteria, forming acid at all stages and encompassing the whole of the bacterial sulfur cycle. The bacteria involved are endemic in anoxic bed sediment, and the process is a response to the presence of steel as an electron donor, and the generation of anoxic microenvironments within corrosion products.

npj Materials Degradation (2019)3:37

; https://doi.org/10.1038/s41529-019-0099-9

\section{INTRODUCTION}

Accelerated low water corrosion (ALWC) (Fig. 1) is an aggressive form of microbially influenced corrosion that may occur on steel in estuarine and marine structures. ${ }^{1-3}$ Corrosion rates on marine steel as high as $1 \mathrm{~mm} / \mathrm{y}$, and typically around $0.3 \mathrm{~mm} / \mathrm{y}$ have been reported, compared to electrochemical corrosion rates in marine environments of around $0.05 \mathrm{~mm} / \mathrm{y}$. This makes ALWC a major threat to marine and coastal infrastructure internationally. Previous work has indicated the role of both sulfate-reducing and sulfur-oxidising bacteria in the formation of $\mathrm{ALWC}^{3-12}$ and highlighted the role of marine nutrient contamination in promoting microbial activity and hence enhanced corrosion rates, $^{13}$ alongside the electrochemical environment within the intertidal zone. ${ }^{14} \mathrm{~A}$ recent study by Malard ${ }^{15}$ identified at least fifteen genera of the Order Desulfobacterales associated with ALWC tubercles. Sulfate-reducing bacteria utilise sulfate, thiosulfate and sulfur as electron acceptors and produce hydrogen sulfide $\left(\mathrm{H}_{2} \mathrm{~S}\right)$ as the product of both $\mathrm{SO}_{4}{ }^{2-}$ and $\mathrm{S}^{0}$ reduction, ${ }^{11,15}$ which may then react with steel to produce iron sulfides ${ }^{11}$ and ultimately pyrite $\left(\mathrm{FeS}_{2}\right)$. Both $\mathrm{H}_{2} \mathrm{~S}$ and pyrite may then be oxidised, producing sulfuric acid, and $\mathrm{Fe}$ oxyhydroxides and sulfates. ${ }^{16}$ However, the full mechanism of ALWC has yet to be elucidated and aspects of its development over time remain unclear. ${ }^{17}$ The introduction of a conductive electron donor (steel) into the marine environment also has the potential to provide a substrate for metabolic mechanisms that have only recently been identified, notably extracellular electron transfer. ${ }^{18,19}$ The phenomenon itself is global and has been reported from all climates, but it is unclear if any apparent spread of the issue is related to transmission of causative bacteria via vectors such as international shipping, or caused by bacteria in local environmental reservoirs such as marine sediment. ${ }^{3}$

In this study, we have combined spectroscopic (Fourier transform infrared (FTIR) and X-ray photoelectron spectroscopy (XPS)) and crystallographic (X-ray diffraction (XRD)) techniques with metagenomic analysis using the Geochip microarray system ${ }^{20,21}$ and related the results to associated bacterial communities in order to determine the precise mechanism of ALWC for a UK site (Shoreham Harbour, Supplementary Fig. 1). This is important not just for its engineering and economic implications, but because it also represents a phenomenon whereby natural microbial communities respond in their development to the presence of an electron donor, anthropogenically introduced into the environment. We have also identified the residence of the individual components of the microbial community within the surrounding environment in order to identify infection vectors for structural steel and environmental risk factors for ALWC. Traditionally, microbiological culture has been employed to determine the composition of microbial communities associated with MIC, but it is time consuming and has a degree of artificiality due to its isolation of the subject microorganism from the original community; a bacterium which is readily cultivatable in the laboratory may be dormant or otherwise have a negligible influence within its community. ${ }^{22}$ In addition, analysis of community interactions is further limited by our current inability to cultivate the majority of bacterial species present in nature; more than 99\% remain uncultivated. ${ }^{23,24}$ The use of a microarray system here gives us the potential to investigate a much wider range of the microbial community and their interaction with steel and the local environment than culture based studies allow.

\section{RESULTS}

Corrosion mineralogy

The results of SEM analysis of ALWC and more typical marine corrosion products from Shoreham Harbour, UK, are shown in Fig. $1 \mathrm{~b}-\mathrm{e}$. The measurements confirmed the presence of iron sulfides on the very inner surface of blisters, and their intergrowth with iron oxyhydroxide-sulfates (identified from XRD and FTIR data) within the blister layer structure (Fig. 1b). The outer surface of the blisters was shown to be composed of iron oxides overlain by a biofilm (Fig. 1c), possibly colonised by a mat of rod-like bacilli, and with widely distributed spheroidal structures composed of $\mathrm{Fe}$ oxides. These possibly result from crystallisation from gel, or are a 

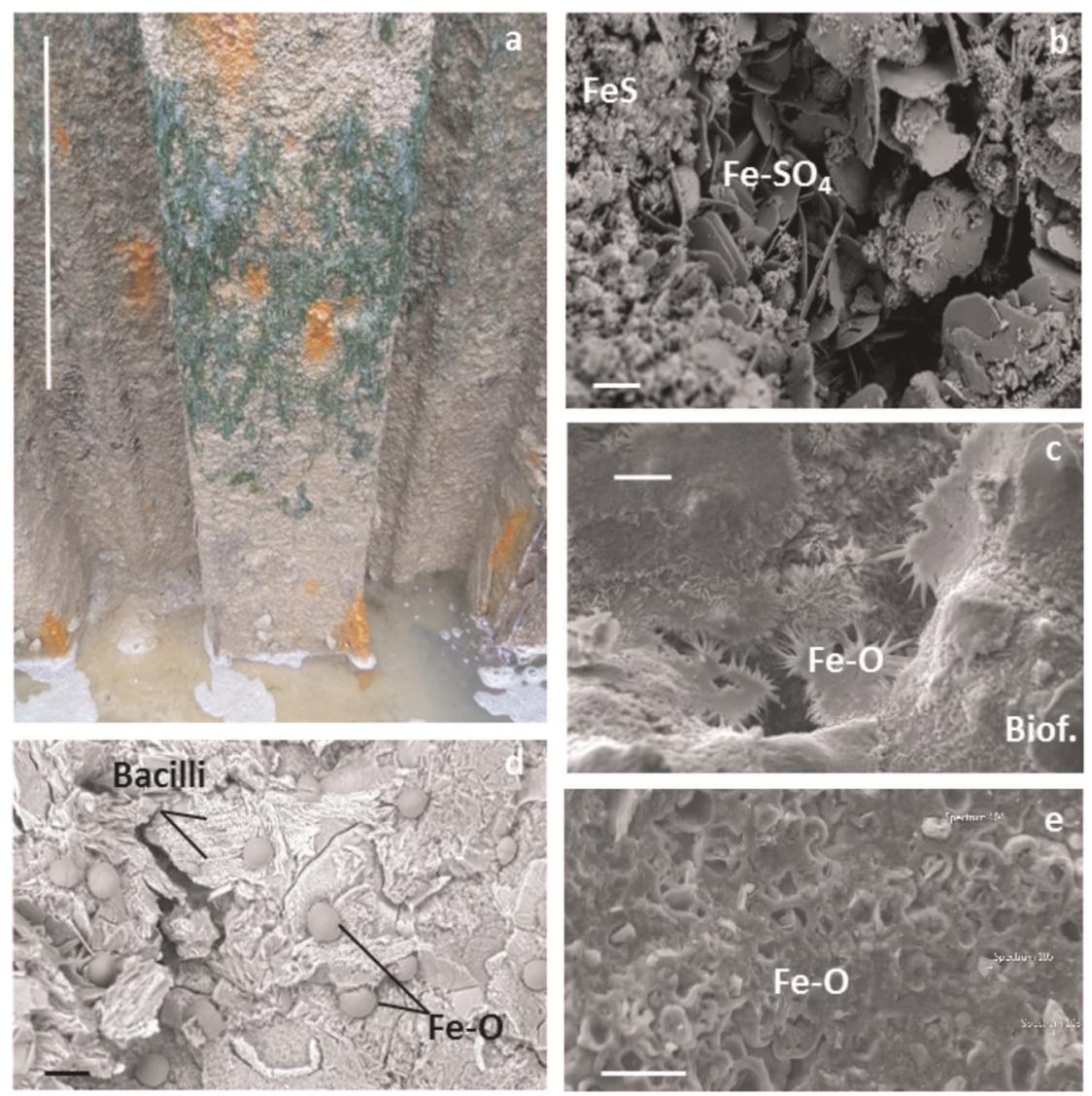

Fig. 1 Images of steel corrosion. a Macroscale ALWC blisters developed on steel pile wall in intertidal zone. Scale bar $50 \mathrm{~cm}$. b High magnification view of inner surface ALWC blister showing amorphous FeS overlying well crystallised Fe sulfates (green rust). Scale bar $10 \mu$ m. c Outer surface of AWLC showing biofilm overlying star like acicular goethite formations (c.f. ${ }^{25}$ ). The depth profile is given by the edge of an $\mathrm{Ar}^{+}$ focussed ion beam ablation crater. Scale bar $10 \mu \mathrm{m}$. d Outer surface of ALWC blister showing rod-like bacilli and the development of Fe oxide or carbonate nodules. Scale bar $10 \mu \mathrm{m}$. e Outer surface of more typical marine corrosion showing microporous toroidal magnetite formation. ${ }^{54}$ Scale bar $25 \mu \mathrm{m}$

product of microbial activity ${ }^{25}$ (Fig. 1d). The association of these with biofilms was also established as diatomaceous algae were observed cemented into the oxide and sulfate.

XRD results are shown in Fig. 2. ALWC blisters are characterised by the presence of sulfate green rust $\left(\mathrm{Fe}^{3+}{ }_{4} \mathrm{Fe}^{2+}{ }_{2}(\mathrm{OH})_{12} \mathrm{SO}_{4} \cdot 2 \mathrm{H}_{2} \mathrm{O}{ }^{26}\right)$, magnetite, maghemite, lepidocrocite $(\gamma \mathrm{FeOOH})$ and/or goethite (aFeOOH). In addition the inner layers show the presence of pyrite $\left(\mathrm{FeS}_{2}\right)$. Aragonite derived from invertebrate shells is variably present in all blisters analysed. Iron fluorescence caused by the use of $\mathrm{Cu} \mathrm{Ka}$ radiation and the presence of amorphous material means that XRD cannot fully identify all the chemical components of the corrosion products.

A summary of the results of FTIR analyses are shown in Fig. 3. Despite broad similarities between patterns from ALWC and typical marine corrosion, there are some differences relating to distinctions in mineralogy and sulfur content, most notably around $850 \mathrm{~cm}^{-1}$ and $1050 \mathrm{~cm}^{-1}$ (shown in representative samples in Fig. 3a). Both sets of analyses show absorption from bond stretching modes characteristic of Fe oxide and oxyhydroxide minerals and Fe hydroxide gels. They also both show strong absorbance by sulfate $\left(\mathrm{SO}_{4}{ }^{2-}\right)$ and bisulfate $\left(\mathrm{HSO}_{4}-\right)$ functional groups, and indications of the presence of amarantite $\left(\mathrm{Fe}^{3+}{ }_{2} \mathrm{O}\right.$ $\left.\left(\mathrm{SO}_{4}\right)_{2} \cdot 7 \mathrm{H}_{2} \mathrm{O}\right)$ and Rozenite $\left(\mathrm{Fe}^{2+} \mathrm{SO}_{4} \cdot 4 \mathrm{H}_{2} \mathrm{O}\right)$, both related to sulfate green rust. The ALWC spectra include, in addition, absorption bands characteristic of pyrite $\left(\mathrm{FeS}_{2}\right)$, thiosulfate $\left(\mathrm{S}_{2} \mathrm{O}_{3}{ }^{-}\right)$and in some instances sulfite $\left(\mathrm{SO}_{3}{ }^{2-}\right)$. Figure $3 \mathrm{~b}$ shows data from 56 samples in terms of band ratios between low absorbance regions and absorbance bands for sulfate and thiosulfate. The thiosulfate absorbance bands clearly differentiate ALWC, although there is a continuum in spectral characteristics reflecting the progressive development of sulfur species in corrosion. Supplementary Table 1 shows the main absorption peak positions identified in each sample, and potential causative molecular groupings.

The utility of XPS in analysis of steel surfaces undergoing corrosion was highlighted by Seyeus et al. ${ }^{27}$ Two samples were selected for X-ray photoelectron analysis, one of ALWC and one of more typical corrosion. The samples were imaged using backscattered electrons after XPS analysis. The outer surface of the ALWC sample had a clearly defined biofilm with a significant chloride content (Fig. 1c). This covered a microcrystalline to amorphous layer of $\mathrm{Fe}$ oxyhydroxides, which in turn covered a layer of crystalline Fe oxides and oxyhydroxides. The inner surface of the ALWC sample was also dominated by Fe oxyhydroxides, but also a well crystalline, Fe-S-O phase identified as sulfate green rust. The normal corrosion sample was uniformly dominated by Fe oxyhydroxides, with poor crystal structures. The inner surface showed a microporous structure that may be important in maintaining fluid contact with the underlying steel and allowing continued corrosion (Fig. 1d).

The results of XPS depth profiling of representative samples of ALWC and normal marine corrosion are shown in Figs 4-6. Analytical data is presented in Supplementary Table 2 and binding energy peak positions are given in Supplementary Table 3. In each case the sample was split into two and mounted for analysis of the outermost and innermost surfaces. In the ALWC sample the 


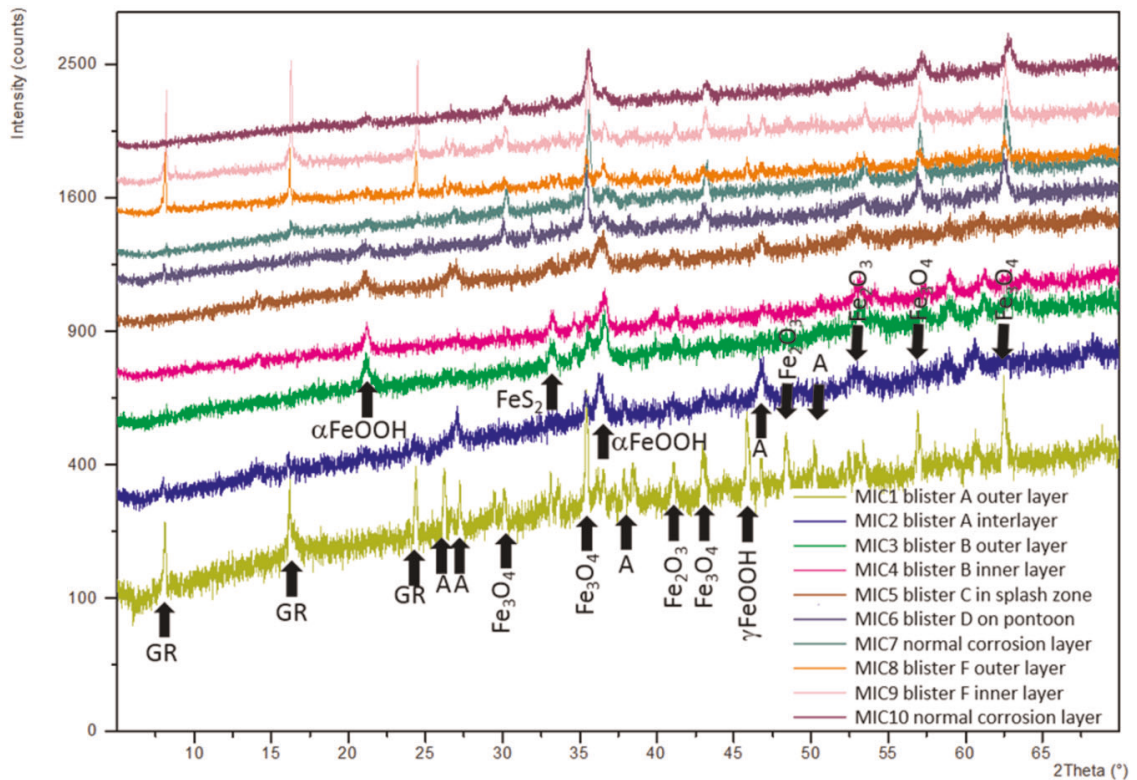

Fig. 2 X-ray diffraction analysis of representative corrosion products. Indicative diffraction peaks for key corrosion phases are noted. Mineral abbreviations and formulae: GR Green rust $\mathrm{Fe}^{3+}{ }_{4} \mathrm{Fe}^{2+}{ }_{2}(\mathrm{OH})_{12} \mathrm{SO}_{4} \cdot 2 \mathrm{H}_{2} \mathrm{O}$, A Aragonite, $\alpha \mathrm{FeOOH}$ Goethite, $\mathrm{Fe}_{3} \mathrm{O}_{4}$ magnetite, $\mathrm{FeS}_{2}$ pyrite, Fe $\mathrm{O}_{3}$ maghemite, $\gamma \mathrm{FeOOH}$ lepidocrocite
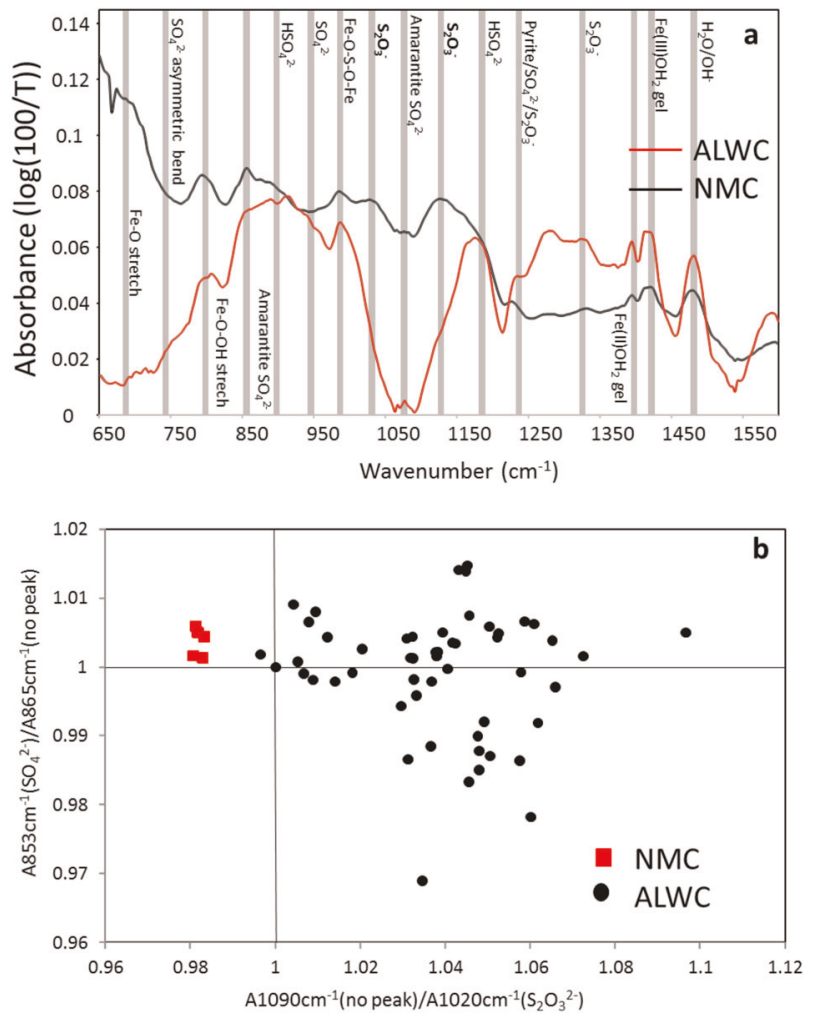

Fig. 3 FTIR spectroscopy of corrosion products. a Shows representative adsorption spectra for typical marine corrosion and ALWC. Adsorption band references are given in Supplementary file. b Adsorption band ratio plot from 45 corrosion samples. Bands were selected to highlight the role of sulfur species, and in particular thiosulfate. Although corrosion types can be distinguished, there is a continuum in sulfur concentration and redox state. Sources for Sspecies adsorption bands are given in Supplementary Table 1 profiles show significant concentrations of $\mathrm{Mg}$ and $\mathrm{Cl}$ throughout, derived from drying of initially seawater-wet samples, and trace levels of $\mathrm{N}$ related to the presence of biofilm material. Iron is more or less constant in concentration throughout the sputtering of the outer surface (Fig. 4a). Alongside iron the dominant component is oxygen, and there is a notable lack of sulfur in the outer layers (typically close to the detection limit of 1 atom \%). Profiles from the very inner surface of the blister outward (Fig. 4a) show sulfur concentrations are significant and reach a maximum (11.5 atom \%) close to the innermost layer. The initial low in S content on the inner surface may reflect post-sampling surface oxidation. Oxygen and iron are still the dominant components. Deconvolution of the Fe $2 p$ binding energy spectrum (Fig. 5a-d) shows characteristic peak shifts in relation to the Fe compounds and bonding environment present. The outermost layer shows the corrosion material is dominated by $\mathrm{Fe}^{3+}$ sulfates $\left(\mathrm{Fe}_{2}\left(\mathrm{SO}_{4}\right)_{3} \cdot \mathrm{XH}_{2} \mathrm{O}\right)$, goethite/lepidocrocite $\left(\mathrm{FeO}(\mathrm{OH})\right.$ ), magnetite $\left(\mathrm{Fe}_{3} \mathrm{O}_{4}\right), \mathrm{Fe}_{2} \mathrm{O}_{3}$ (probably as maghemite by comparison with XRD data), iron carbide $\left(\mathrm{Fe}_{3} \mathrm{C}\right)$ and $\mathrm{FeO}$ (Fig. 5a). The same range of compounds was identified after sputtering, but with metallic iron particles, pyrite $\left(\mathrm{FeS}_{2}\right)$ and $\mathrm{FeS}$ present (Fig. 5b). FeS may be present as amorphous iron sulfide, or as mackinawite, ${ }^{11}$ but mackinawite has not been identified by XRD in this study. Despite the presence of sulfate compounds the sulfur concentration in the outer layers is low $(<5$ atom \% compared to up to 15 atom \% close to the inner surface). The same process for the innermost layers shows the presence of magnetite, maghemite/hematite, and iron sulfide compounds (Fig. $5 c$, d). Examining the $S 2 p$ binding energy fine structure (Fig. 5e, f), shows that after sputtering the sulfur speciation can be seen to be dominated almost entirely by iron monosulfide FeS, with a smaller component of pyrite $\left(\mathrm{FeS}_{2}\right)$ and cluster type compounds. All major phases and non-crystalline components identified by XPS are confirmed by the XRD and FTIR data.

In the normal marine corrosion sample there are significant differences in the XPS profiles. Carbon is abundant in the outermost layer (Fig. 4b), partly present as aragonite/calcite from the biofouling of the steel. After sputtering the outer part of the corrosion layer is shown to be dominantly $\mathrm{Fe}$ and $\mathrm{O}$, but $\mathrm{N}$ and $\mathrm{S}$ occur at trace levels throughout. The maximum sulfur 

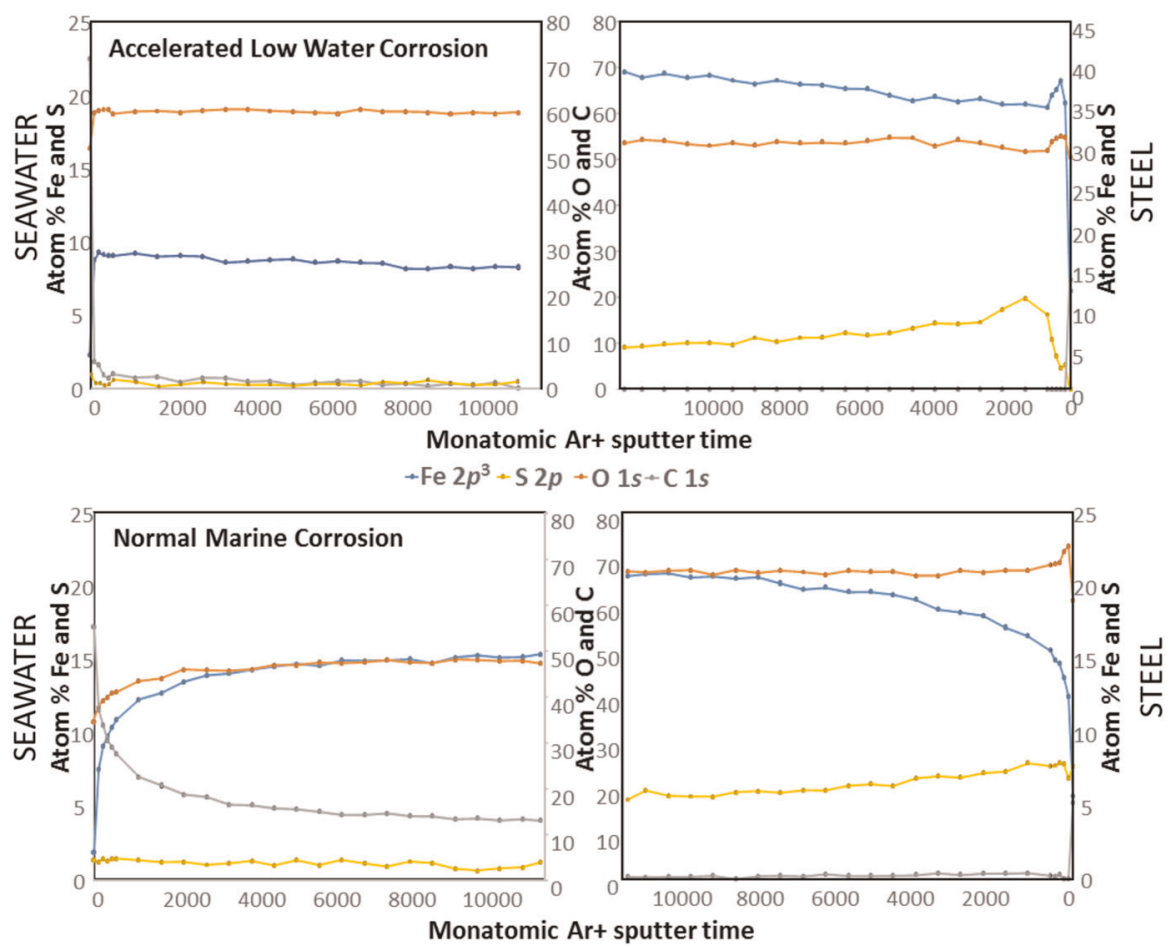

Fig. 4 Corrosion product composition as atomic percent from broad scan XPS spectroscopy. Sputter time axes are reversed on the right to show the profile from seawater to steel based on the depth profiles from the outer and inner surface of the corrosion samples. Sulfur is present throughout typical marine corrosion, with concentration increasing towards the steel surface, whilst sulfur concentration in ALWC is higher, but shows a much more strongly layered structure. Sulfur is below detection in the outer layers, but strongly concentrated at the steel surface

concentration is $\sim 2$ atom $\%$ and mainly around $\sim 1$ atom $\%$ making it significantly less abundant than in the ALWC blister (Fig. 4b). The inner surface is also dominantly $\mathrm{Fe}-\mathrm{O}$, but with up to $\sim 8$ atom $\% \mathrm{~S}$ (Fig. 4b). The Fe $2 p$ spectra on the inner side of the corrosion layer after sputtering shows the dominant sulfur compound is $\mathrm{Fe}^{3+}$ sulfate $\left(\mathrm{Fe}_{2}\left(\mathrm{SO}_{4}\right)_{3} \cdot \mathrm{XH}_{2} \mathrm{O}\right)$, goethite/lepidocrocite, magnetite and trace pyrite (Fig. 6a, b). The innermost layer of the corrosion (i.e. with no sputtering) consists of maghemite, green rust and goethite/lepidocrocite. Examination of the $S 2 p$ binding energy fine structure (Fig. $6 c$, d) shows the $S$ in the innermost layer to be dominantly $\mathrm{Fe}_{2}\left(\mathrm{SO}_{4}\right)_{3} \cdot \mathrm{XH}_{2} \mathrm{O}$, whilst after sputtering a more complex mineralogy is revealed. This includes $\mathrm{Fe}_{2}\left(\mathrm{SO}_{4}\right)_{3} \cdot \mathrm{XH}_{2} \mathrm{O}$, sulfite and pyrite. Further analysis to determine the relative proportion of sulfur compounds was carried out. The very innermost layer (i.e. with no sputtering) is almost entirely $\mathrm{Fe}_{2}\left(\mathrm{SO}_{4}\right)_{3} \cdot \mathrm{XH}_{2} \mathrm{O}$, whilst in the interior of the corrosion layer, the $1 \%$ total $\mathrm{S}$ is composed of $20 \% \mathrm{FeS}, 40 \% \mathrm{Fe}_{2}\left(\mathrm{SO}_{4}\right)_{3}$ and $40 \% \mathrm{SO}_{3}{ }^{2-}$. Iron mineralogy is always dominated by $\mathrm{Fe}$ oxide species.

The iron species binding energy peaks show a number of complexities in the interpretations above. The observed binding energy depends not only upon initial state effects (the charge on the atom), but also final state effects, especially electron relaxation. In this case, $\mathrm{S}_{2}{ }^{-2}$ in $\mathrm{FeS}_{2}$ is highly polarisable and therefore has large relaxation effects. Due to this final state effect, $\mathrm{FeS}_{2}$ has lower binding energy than $\mathrm{FeS}$. In $\mathrm{Fe}_{3} \mathrm{O}_{4}$, both $\mathrm{Fe}^{2+}$ and $\mathrm{Fe}^{3+}$ are present. Fe $2 p_{3 / 2}$ core level BE peaks of $\mathrm{Fe}$ (II) and $\mathrm{Fe}(\mathrm{III})$ appear at $\sim 709.8 \mathrm{eV}$ and $\sim 710.8 \mathrm{eV}$ respectively. On the other hand, in $\mathrm{Fe}_{2} \mathrm{O}_{3}$, Fe is only in the +3 oxidation state. So the Fe $2 p_{3 / 2}$ core level peak should appear around $\sim 710.8 \mathrm{eV}$. For that reason, $\mathrm{Fe}_{3} \mathrm{O}_{4}$ is assigned to $709.8 \mathrm{eV}$ and $\mathrm{Fe}_{2} \mathrm{O}_{3}$ is assigned to $710.8 \mathrm{eV}$. References for binding energy peak positions are given in the Supplementary Table.

The results indicate the inner surfaces of ALWC blisters are dominated by iron monosulfide and pyrite (up to 15 atom\% S).
These are oxidised on their outer surfaces to a range of green rust compounds. The outer materials also include goethite, magnetite and maghemite/hematite, and minor amounts of relict steel phases. Fourier transform infrared spectra of corresponding samples show the presence of the same Fe phases, but also sulfite $\left(\mathrm{SO}_{3}{ }^{2-}\right)$ and thiosulfate $\left(\mathrm{S}_{2} \mathrm{O}_{3}{ }^{-}\right)$. X-ray photoelectron spectroscopic analyses of more typical marine corrosion products show much lower $\mathrm{S}$ concentrations (1-5 atom \% S), with S dominantly present as sulfate in mixed Fe oxidation state sulfate green rust, amarantite and rozenite. Pyrite is still present in the normal marine corrosion, but in much lower concentrations associated with the inner surface of corrosion.

\section{Microbiology of ALWC}

Microbial community functional structures of eighteen samples: three duplicates of two microbially influenced corrosion samples (BT and DBMIC); three duplicates of two seawater samples (BT and DBWAT); and three duplicates of two bed sediment samples (BT and DBSED) were analysed with GeoChip 5.0 (Glomics Inc.) and the results are summarised in Supplementary Table 4. Details of the sample sites are given in the methods section-the Brighton Terminal (BT) is in a non-tidal lagoon and the Dredger Berth (DB) is in a tidal area connecting to the main estuary. The number of detected genes sequences were between 30,294 and 51,748 depending on the samples. The alpha-diversity (richness and evenness) of the microbial communities was assessed using the Shannon-Wiener index $(H)$, Simpson index $(1 / D)$ and Simpson evenness $(E){ }^{28}$ The Shannon-Weaver index values were from 8.47 to 9.91 across the samples, showing a high diversity in all samples and no significant differences among them. Consistently, the $1 / D$ (values from 713 to 5468 ) and $E$ (values from 0.02 to 0.11 ) indices did not show any significant differences between the samples. At the phylogenetic level, 32 bacterial phyla and up to 1948 bacterial species (depending on the sample) were detected in the samples 

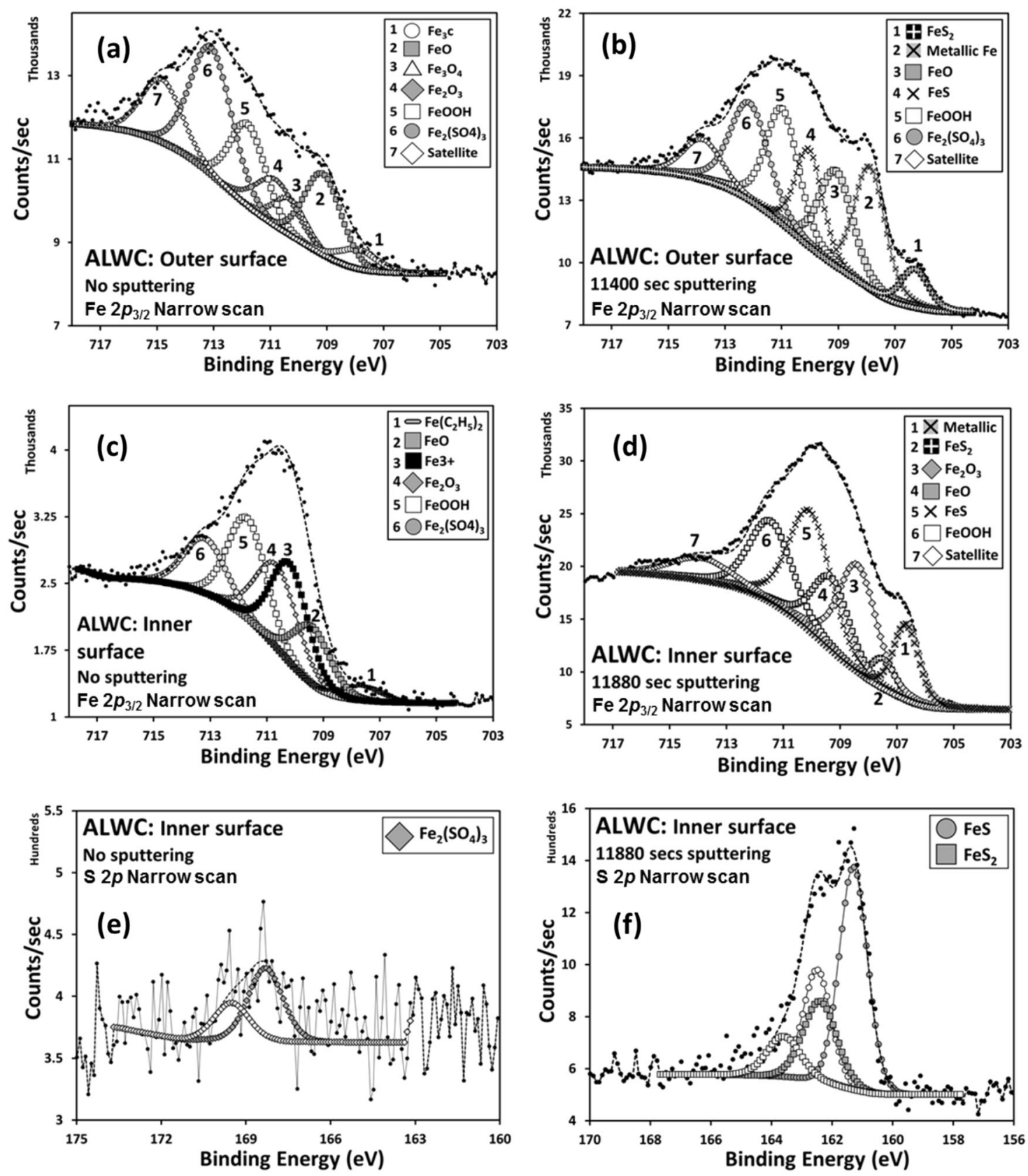

Fig. 5 XPS narrow scan spectroscopy of typical ALWC products. References for chemical shifts are given in supplementary file. (a) $+(\mathbf{b})$ Fe $2 p_{3 / 2}$ narrow scan spectra from start and end of argon sputtering of the outer surface. (c) + (d) Fe $2 p_{3 / 2}$ narrow scan spectra from start and end of sputtering of the inner surface. (e) and (f) $\mathrm{S} 2 p$ narrow scan spectra from start and end of ablation of the inner surface. Peak assignments are numbered for figure (a) to (d). And for (e) and (f), open symbols represent $2 p_{1 / 2}$ and closed symbols represent $2 p_{3 / 2}$ of Sulfur narrow scan data

with the most predominant phyla being Proteobacteria 57\%, Actinobacteria 21.3\%, Firmicutes 9.3\%, Bacteroidetes 3.5\%, Cyanobacteria $2.5 \%$, Deinococcus-Thermus $1.4 \%$, and Chloroflexi $1.1 \%$. All the others were represented by less than $1 \%$. These data show a high diversity of microbial communities in the different samples.

When looking at the microbial biogeochemical cycles gene categories, genes related to the carbon cycle were the most present in all samples, with variations in the intensity depending on the sample. Genes related to nitrogen, phosphorus and sulfur cycles were found in lower intensity than carbon cycle and showed no significant differences between all samples. We specifically focused the analyses on the sulfur cycle functional genes as these are inferred to be involved in the key biochemical processes in ALWC. ${ }^{11,15}$ The genes and related mechanisms studied were $a p r$, and $c y s H$ (sulfate reduction), ${ }^{28} d s r$, sir, and cysl and cysJ (sulfite reduction); ${ }^{29-31} \mathrm{fcc}$, and sar (sulfide oxidation), ${ }^{29,30,32-35}$ and sox (thiosulfate oxidation). ${ }^{36-38}$ All these genes were derived from 461 different bacterial species belonging to 29 phyla, with the most abundant being the Proteobacteraciae (31.1\%) followed by the Firmicutes (3.3\%); Actinobacteriacea (2.3\%); and the Chlorophyta (2.1\%). Genes involved in sulfate reduction, sulfite reduction, sulfide oxidation, and thiosulfate oxidation show a broadly similar pattern between samples for each of the two environments (Fig. 7). Within BT, seawater displays the greatest level of gene expression between each metabolic category, whereas sediment and ALWC show broadly similar levels of activity. The DB samples indicate the highest activity is within 

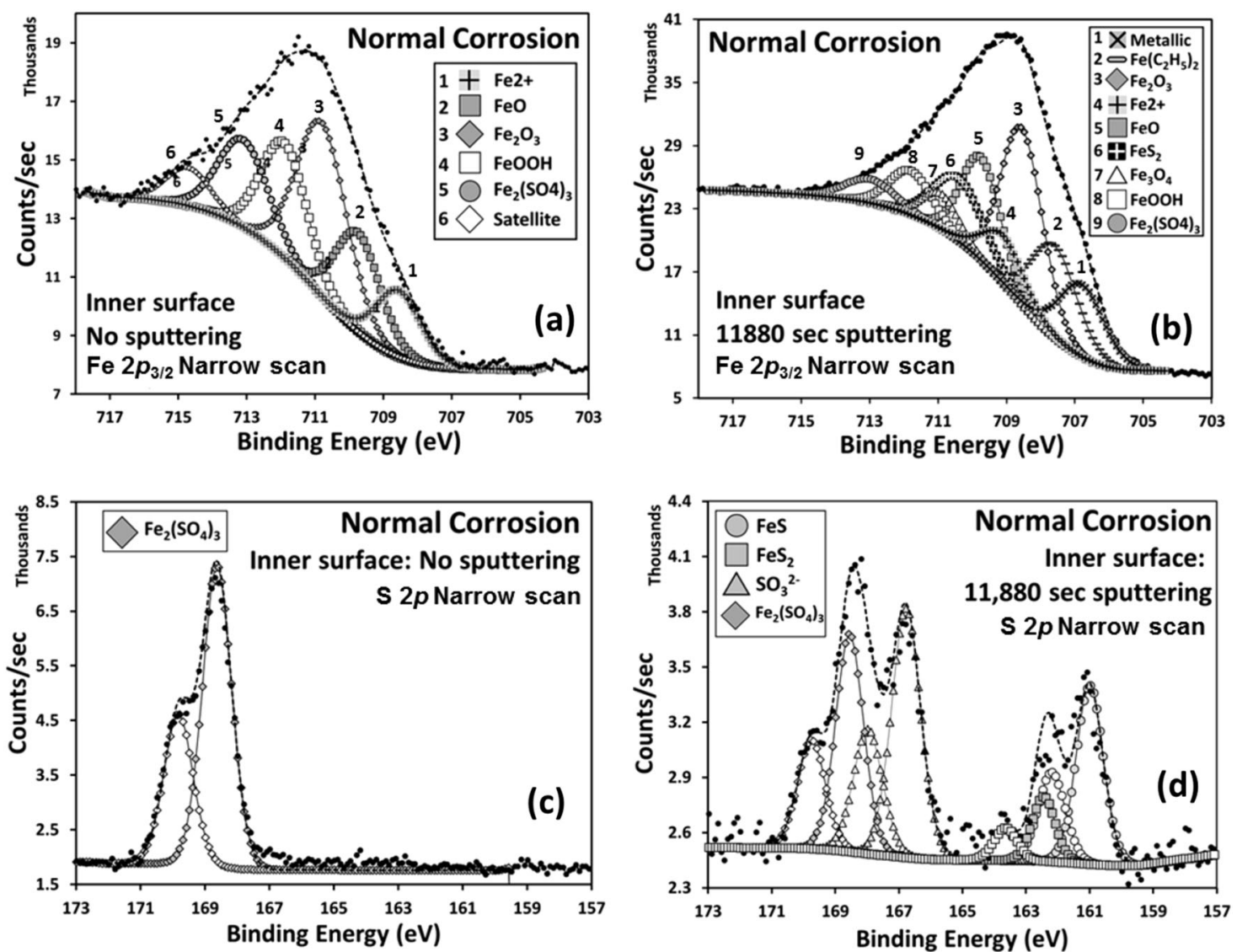

Fig. 6 XPS spectroscopy of typical marine corrosion products. References for chemical shifts are given in in Supplementary Table 2. (a, b) Fe $2 p$ narrow scan spectra from start and end of argon sputtering of the inner surface. Corrosion mineralogy is dominated by Fe III species, with minor Fe-S compounds. (c, d) S $2 p$ narrow scan spectra from start and end of ablation of the inner surface. Sulfate is the dominant species, with minor sulfide and sulfite developed dispersed throughout the corrosion layer. Open symbols are the $S 2 p_{1 / 2}$ electron spin pairing, and closed symbols are $S 2 p_{3 / 2}$ electron spin paring binding energies

the marine sediment, with seawater displaying the lowest degree of gene expression. When focusing the analysis on genes involved in sulfide and thiosulfate oxidation, and sulfate and sulfite reduction, we observed that gene expression was broadly similar between categories, with no dominant gene or metabolic pathway being apparent.

The aprA, aprB and cys $H$ genes were active in 51, 30 and 9 species respectively; composed on average of Proteobacteriacea (53.4\%); Firmicutes (8.2\%); Ascomycota (4.8\%); and Crenarchaeota (3.4\%). Thirty-four percent of the detected genes were from uncultured microorganisms. The $d s r A$ and $d s r B$, genes were found in 58, and 52 species, respectively; whereas the cysl, cysJ and sir genes were active in 121, 115 and 116 species respectively. The species distribution was Proteobacteriacea (31.7\%); Firmicutes (6.0\%); Actinobacteria (3.9\%); Euryarchaeota (2\%); Crenarchaeota (1.3\%); Cyanobacteria (1.5\%). Twenty-six of the detected genes were found in uncultured bacteria. The $f C C A B$ gene was found in 38 species; the sir gene, only 14 species. These were found to belonging mainly to Proteobacteriacea (62.7\%); Chlorobia (7.9\%); Actinobacteria (3.2\%); Aquificae (3.2\%) and Deinococcus-Thermus (2.4\%). Twenty-nine percent of the detected genes were found in uncultured bacteria. Of the sox genes, the sox $A$ and sox $B$ genes were observed in 14 and 5 species only. The sox $C$ and sox $Y$ genes were found in 37 and 24 species. The dominant phylum was Protecobacteriacea (86.4\%); with Chlorobia comprising 7\%; Deinococcus-Thermus (2\%) and Aquificae (1\%). Most of the genes could be attributed to a species (only $2.4 \%$ of the genes were found in uncultured bacteria).
When analysing the intensity of each gene, eight species represented $56 \%$ of the total intensity of all $d s r A / B$ genes that could be attributed to a species: Desulfobulbus propionicus (9\%), Holdemania filiformis (8\%), Clostridium leptum (6\%), Moorella thermoacetica (6\%), Desulfovibrio alaskensis (6\%), Desulfovibrio vulgaris (5\%), Thioalkalivibrio sulfidophilus (5\%) and Acetobacterium woodii (3\%). For sqr gene, six species represented $79 \%$ of the total intensity that could be attributed to a species: Chlorobaculum tepidum (17\%), Bradyrhizobium diazoefficiens (17\%), Thiorhodospira sibirica (15\%), Teredinibacter turnerae (14\%), Mycobacterium parascrofulaceum (9\%) and Rhodospirillum centenum (7\%). For soxY gene, eight species represented $61 \%$ of the total intensity that could be attributed to a species: Nitrobacter hamburgensis (19\%), Methylobacterium populi (13\%), Methybacterium nodulens (7\%), Ruegeria pomeroyi (6\%), Sideroxydans lithotrophicus (5\%), Chlorobium phaeovibrioides (5\%), Methylosinus trichosporium (3\%), Halothiobacillus neapolitanus (3\%). Interestingly, soxABCV genes were present in different species: Thermus aquaticus (20\%), Methylobacterium extorquens (14\%), Hyphomonas neptunium (5\%), except Ruegeria pomeroyi (4\%) that carried both soxY and soxABCV genes. None of the species was specific to any samples type (seawater, sediment or ALWC). The full results of metagenomic analyses using Geochip and 16s RNA analysis are shown in Supplementary Table 4 and summarised in Fig. 7. The range of species and gene activity identified covers most of the active sulfur cycle, ${ }^{39}$ including species involved in intermediate sulfur species disproportionation, and those implicated in the use of extracellular electron transfer. ${ }^{18,19}$ 

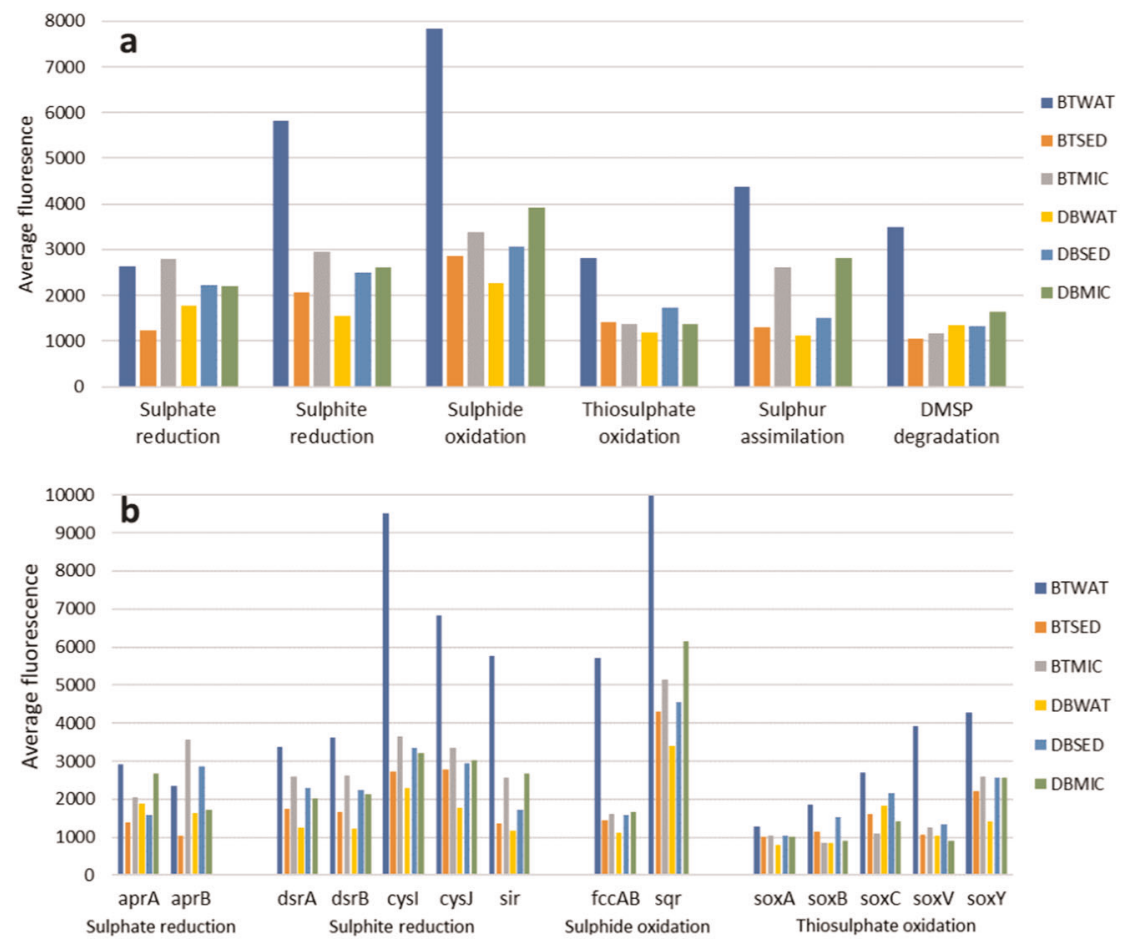

Fig. 7 Results of metagenomic analysis of corrosion products and environmental samples, Shoreham Harbour, UK, via GeoChip. a Gene expression for biochemical pathways involved in sulfur cycling. b Relative abundance of genes responsible for sulfate reduction, sulfite reduction, sulfide oxidation and thiosulfate oxidation

Discussion-mineralogy, microbiology and the mechanism of ALWC

The data presented here allow identification of the mechanism of ALWC within the local harbour environment. In this setting normal marine corrosion typically has an outer layer, including calcium carbonate, from a macro-biofilm, overlying layers of goethite and magnetite associated with minor amounts of a range of iron-sulfur compounds. These are not limited to sulfate green rusts, but also include small amounts of FeS and sulfite compounds $\left(\mathrm{SO}_{3}{ }^{2-}\right)$. In ALWC samples outer layers of goethite, magnetite, maghemite and Fe (III) sulfate with progressively higher S contents moving inwards, form over a layer of FeS (as mackinawite or amorphous iron sulfide) and pyrite $\left(\mathrm{FeS}_{2}\right)$, with minor green rust components. More strongly developed minor components in ALWC include sulfite $\left(\mathrm{SO}_{3}{ }^{2-}\right)$ and thiosulfate $\left(\mathrm{S}_{2} \mathrm{O}_{3}{ }^{2-}\right)$ compounds. Iron (II) oxide ( $\mathrm{FeO}$ ) also occurs as a minor phase, alongside relics of un-oxidised steel including iron metal $\left(\mathrm{Fe}^{0}\right)$ and iron carbide $\left(\mathrm{Fe}_{3} \mathrm{C}\right)$ and highly metastable phases including $\mathrm{Fe}(\mathrm{III})$ $S$ compounds. The inferred major mineralogy is in keeping with previous studies of ALWC mineralogy.

The formation of the FeS layer in ALWC in particular is widely recognised as the key factor in driving accelerated corrosion rates. ${ }^{19,25}$ These studies have proposed 2 main mechanism for microbially mediated corrosion:

Electrical microbially influenced corrosion (EMIC):

$4 \mathrm{Fe}^{0}+\mathrm{SO}_{4}^{2-}+3 \mathrm{HCO}_{3}^{-}+5 \mathrm{H}^{+}=\mathrm{FeS}+3 \mathrm{FeCO}_{3}+4 \mathrm{H}_{2} \mathrm{O}$

Chemical microbially influenced corrosion (CMIC):

$3\left[\mathrm{CH}_{2} \mathrm{O}\right]+2 \mathrm{Fe}^{0}+2 \mathrm{SO}_{4}^{2-}+\mathrm{H}^{+}=3 \mathrm{HCO}_{3}^{-}+2 \mathrm{FeS}+2 \mathrm{H}_{2} \mathrm{O}$

$\mathrm{H}_{2} \mathrm{~S}+\mathrm{Fe}^{0}=\mathrm{H}_{2}+\mathrm{FeS}$

In the former (EMIC, Eq. 1) SRB attack iron via withdrawal of electrons directly by metabolic coupling and the formation of an electrically conductive FeS layer. Although this has the potential to greatly increase corrosion rates it has been suggested to be less common, and most proposed mechanisms include the formation of Fe carbonates which have not been observed here. It is also proposed to occur in the absence of organic matter, which observation of blisters and data from XPS suggest is not the case. The initial corrosion of the steel surface by SRBs in the ALWC samples is by the generation of $\mathrm{H}_{2} \mathrm{~S}$ by sulfate reduction, followed by reaction to form $\mathrm{FeS}^{11}$ and by the overall process of organic matter oxidation and sulfate reduction (CMIC, Eqs. 2 and 3). The enhancement of corrosion by direct attack of steel by $\mathrm{H}_{2} \mathrm{~S}$ to generate mackinawite was noted by Little et al. ${ }^{11}$ The production of pyrite is either direct, or as recrystallisation and oxidation of FeS. An observation from this study is the widespread presence of intermediate sulfur oxidation products within ALWC. These could be the result of oxidation of FeS on exposure to the atmosphere. However, all samples were stored in anoxic jars post-collection, and both iron and sulfide-oxidising bacteria have been detected associated with ALWC in this and other studies. ${ }^{4}$ The formation of reactive intermediate oxidation state sulfur compounds via microbial sulfur oxidation therefore has a key role to play in the development of ALWC. Simple thermochemical oxidation of $\mathrm{H}_{2} \mathrm{~S}$ may play a major role in enhancing corrosion through the generation of low $\mathrm{pH}^{40}$ Direct oxidation of pyrite and FeS may have a similar effect, as may sulfide oxidation in the presence of $\mathrm{Fe}^{3+}$ from the outer layers of the blisters. ${ }^{41}$ These reactions are illustrated in Fig. 8. However, pyrite (and by analogy FeS) oxidation has been demonstrated to be a multistage process, ${ }^{41,42}$ with potential microbial involvement throughout. ${ }^{39,43}$ The reaction sequence involved has been summarised by [42] and is shown in relation to $\mathrm{S}$ compounds identified in ALWC in Fig. 8. Acidity $\left(\mathrm{H}^{+}\right)$ is generated throughout this process. It also involves disproportionation, whereby microbial metabolism uses intermediate oxidation state sulfur compounds as both electron acceptors and donators and hence produces both oxidised and reduced sulfur species as products, ${ }^{39}$ Within this process the formation of sulfated iron compounds of varying stoichiometry is further driven by the oxidation, in the presence of seawater, of $\mathrm{Fe}^{2+}$ released to 


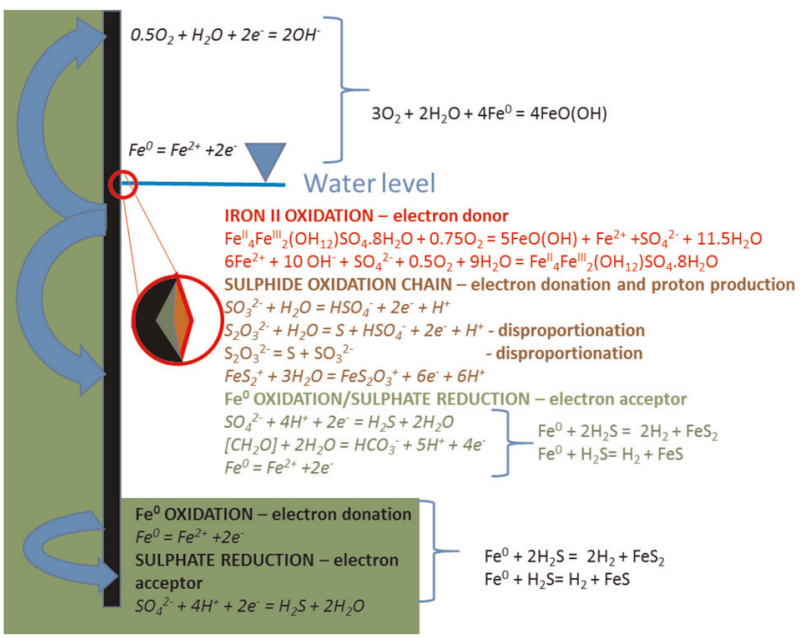

Fig. 8 Summary of the reaction pathways for steel corrosion in tidal marine environments, highlighting electron acceptors and electron donors. Half reactions are given in italics and net reactions in plain text. Every step of the sulfide oxidation reaction chain generated electrons and protons that can be consumed by the sulfate reduction process. The development of the full microbial sulfur cycle occurs within corrosion microenvironments, and leads ultimately to the development of ALWC blisters with a layered structure. The emergence of blister structures generates an extremely corrosive microenvironment, conducive to the action of sulfate-reducing bacteria, which is protect from the oxic water column via the development of an outer layer of iron oxides and green rusts

solution ${ }^{35}$ which in turn contributes to formation of lepidocrocite/ goethite. ${ }^{31,35}$ In addition to these processes XPS data indicate the presence of minor amounts of Fe-S cluster type compounds $\left(\mathrm{Fe}_{3} \mathrm{~S}\right)$ that may be indicative of further microbial metabolism.

The XPS data also indicate low concentrations of $\mathrm{FeS}$ and intermediate oxidation state compounds within normal marine corrosion blisters. This indicates a continuum in corrosion typesthe presence of anaerobic microenvironments within the splash zone allowing for a minor SRB involvement in normal corrosion generating possible initiation sites for ALWC, or a component of EMIC during periods of steel wetting above the high tide mark. Little et al. ${ }^{11}$ noted that abiotic aqueous synthesis of these minerals requires $\mathrm{H}_{2} \mathrm{~S}$ pressures higher than those found in shallow waters.

All the reactions identified from spectroscopic data above are partially or wholly microbially mediated. ${ }^{38}$ The high number of detected genes (up to 51,748 functional genes), the alphadiversity results and the number of species found in the samples (32 bacterial phyla and up to 1948 bacterial species) reveal a high bacterial diversity within the corrosion samples studied here. All samples show common species, but closest correspondence is between corrosion samples and samples from $50 \mathrm{~cm}$ depth in bed sediment. We conclude from this that the source of corrosion causing bacteria is anoxic environments within bed sediment, with a transport vector via sediment suspension in seawater.

Many functional genes from 384 species (belonging to 16 phyla) are involved in the sulfur cycle showing a high bacterial diversity for this biochemical pathway. The high number of genes having the same function (for instance, 320 and 229 different $d s r A$ and $d s r B$ genes, respectively) and the high number of species carrying one type of functional gene suggest a high functional redundancy, ensured by a mix of species able to perform the same biochemical reactions. This functional redundancy is important to ensure an ecological stability if any individual species is lost due to environmental change. This is also supported by the fact that

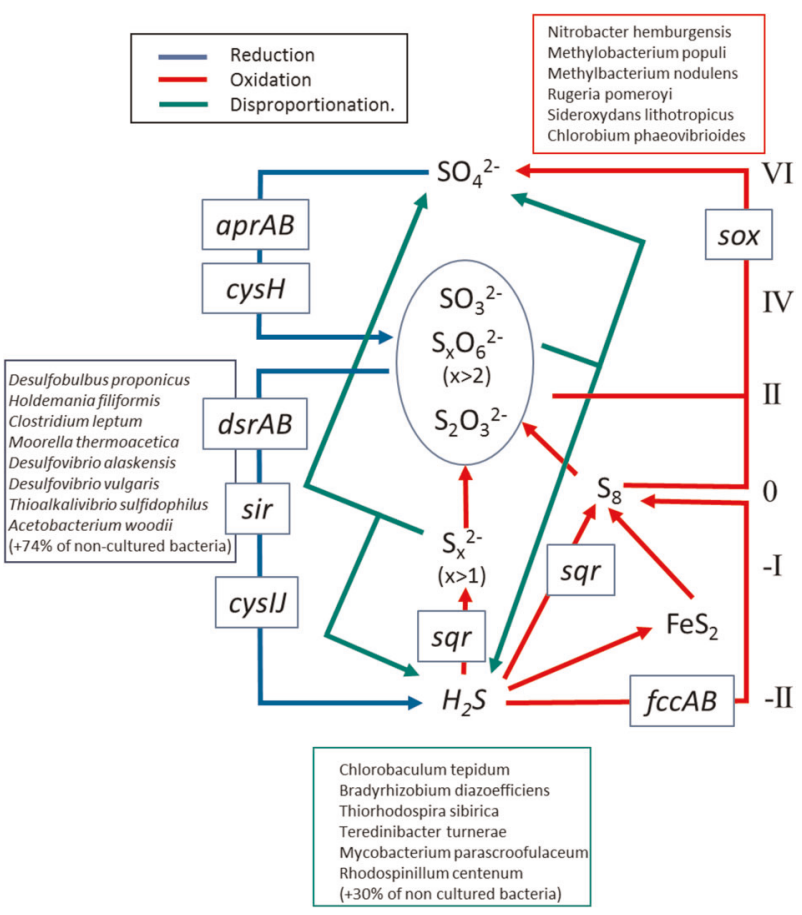

Fig. 9 Summary of the sulfur redox cycle in marine environments, adapted from Hansel et al. ${ }^{39}$ with the microbial species utilising each metabolic pathway (sulfate reduction, sulfide oxidation, sulfite and thiosulfate disproportionation) identified from ALWC samples. Roman numeral show the $S$ oxidation state at each stage

none of the species are numerically dominant and most species seem to contribute to the biochemical reaction of a gene. Genes involved in the sulfate reduction process were the most detected amongst the sulfur cycle genes, followed by sulfur and sulfide oxidation. A few genes play an important part in the sulfur cycle reactions in sediment and MIC: $d s r A B$, sqr and soxY. The $d s r A$ and $d s r B$ genes have been previously identified as involved in ALWC, mainly mediating sulfate reduction but also, for some species, sulfide oxidation. ${ }^{9,44,45}$ The sqr and soxy genes are known to be involved in sulfide and sulfur oxidation.

From a phylogenetic point of view, $d s r A B$ genes were mainly found in uncultured bacterial strains (74\%), with the remainder derived from 61 species belonging to Proteobacteriaceae and Firmicutes. A recent study on the phylogenetic diversity of $d s r A B$ genes showed that at least 13 lineages gathered uncultured bacteria and 3 of them occurred mainly in marine environment, ${ }^{46}$ suggesting that the major taxa of SRB have not yet been identified in this context. The sqr gene was less diversified than $d s r A B$ genes and was found in $30 \%$ of uncultured bacteria and in 21 cultivable species. The soxY gene was found almost exclusively in 63 cultivable species, $83 \%$ belonging to Proteobacteriacea. The genes involved in the sulfur oxidation were mainly represented by sox $Y$ gene and soxABCV genes were detected with a very low intensity. The oxidation reactions could also be attributed to other species or genes such as $d s r A B$ genes found in Chlorobium sp. ${ }^{47}$ Finally, the phylogenetic data showed us that there is an exchange of bacteria between the three matrices (seawater, sediment and MIC) as they share the same species for the key genes involved in ALWC. The overall bacterial involvement in the sulfur cycling linked to ALWC is summarised in Fig. 9. The identification of this range in bacteria highlights the importance of the metagenomic approach using a microarray in characterising natural microbial populations, compared to ex situ culturing studies.

The data collected here allow identification of the mechanism of ALWC in this setting. The mechanism of initial colonisation of steel surfaces within the oxic water column and intertidal zone 
remains to be directly determined, although the concentration of defects on steel pile bends has been identified as a factor. ${ }^{47}$ The formation of anoxic microenvironments behind macro-biofilms (algae; sea squirts, barnacles) due to the decomposition of organic matter is one possible initiation point, and bacterial adhesion is facilitated by the initial formation of extracellular polymeric substances ('slime') in the biofilm. ${ }^{48}$ Minor colonies of SRBs also develop in oxygen depleted pore space within normal marine corrosion, ${ }^{49,50}$ as indicated by the generation of sulfides within more typical corrosion samples. The generation of anoxic microenvironments leads to $\mathrm{H}_{2} \mathrm{~S}$ generation by sulfate-reducing bacteria against the steel surface. The subsequent oxidation of iron sulfides, via a range of reactive intermediate compounds, generates protons at every stage. This increases the corrosion potential of the process and generates an environment conducive to SRB metabolism. The generation of $\mathrm{H}_{2} \mathrm{~S}$ by sulfate-reducing bacteria and its mineralisation against the steel surface is a key factor in the enhanced corrosion rate, both as iron is oxidised as an electron donor in electrochemical reactions, and by iron sulfide mineralisation. The generation of an oxidised layer by sulfur- and sulfide-oxidising bacteria protects the SRB colonies from the atmosphere and oxic water column, allowing the process to continue. The ultimate development of high concentrations of $\mathrm{H}_{2} \mathrm{~S}$ and its oxidation to sulfuric acid results in the die off of the macrobiota forming the biofilm, exposing the ALWC blister at the surface. The mineral paragenesis developed during this process is in contrast to that proposed by Jeffrey and Melchers, ${ }^{25}$ where iron oxyhydroxides were proposed to be converted to sulfide phases by bacterial processes and highlights the importance of determination of iron and sulfur oxidation state in phase identification.

The SRB species implicated in ALWC have been identified in samples from $50 \mathrm{~cm}$ below the sediment bed surface. This indicates that the marine bed sediment environment is a reservoir for causative species, and sediment resuspension in the marine water column a vector for transport of microbes to the steel surface. Bed sediment anoxia in organic-rich, silt and clay grade sediment is a key component of the electrochemical environment of marine steel, but because of the indigenous microbial populations may also be a fundamental environmental risk factor for ALWC. The identification of ALWC linked microbial populations in the wider environment, and the diverse range of bacteria involved in each metabolic pathway indicates that the phenomenon is emergent as a result of the introduction of an electron donor into the intertidal environment, and not the result of the spread of a single causative organism, or community of organisms, over a period of time.

The range of techniques applied here have allowed the identification of the microbial mechanisms behind ALWC in at a single site. The mineralogical products have also been identified in a number of studies ${ }^{11,16}$ and are consistent with other UK and Australian sites. ${ }^{5,14,25}$ The presence of intermediate oxidation state sulfur compounds has not been previously reported, although they are implicated as products in sulfide corrosion. ${ }^{11} \mathrm{~A}$ range of SRB and SOB species have previously been reported from ALWC occurrences, and many of the species identified here are widespread in marine sediment. The overall mechanism identified here may therefore be occurring more generally in ALWC, although the precise microbial community is likely to vary from site to site.

Detailed spectroscopic and metagenomic analysis of ALWC mineralogy and chemistry has provided the evidence to support an integrated model for its formation for a UK harbour site. Iron sulfides are generated against marine steel surfaces via bacterial sulfate reduction, generating $\mathrm{H}_{2} \mathrm{~S}$, which subsequently reacts with steel. The sulfides are oxidised via a range of intermediate Fe and $S$ oxidation state compounds representing reactive intermediates between iron monosulfide and iron oxyhydroxides and sulfatehydroxides. These are important in the ALWC process as each oxidation step identified has the potential to further generate protons (acidity) that may enhance the steel corrosion process. Metagenomic analysis has identified microbial populations with genes for sulfate reduction, accompanied by sulfide oxidation, sulfite reduction, sulfur assimilation, thiosulfate oxidation and sulfur oxidation within ALWC blisters that are responsible for mediating this sulfide oxidation reaction train. The processes involved in ALWC encapsulate virtually the whole microbial sulfur cycle. The process has emerged as a result of the introduction of an electron donor into the marine environment rather than the spread of a causative organism, and as such is an example of the development of microbial communities in response to environmental change. Further studies are now necessary to confirm these conclusions in other anthropogenically modified marine environments. Identification of causative mechanisms is the first step in improving approaches to address a microbially mediated process with global economic impact. From this study both microbial community identification and the use of FTIR to identify diagnostic compounds could support early identification of the problem in the future.

\section{METHODS}

\section{Sampling}

Samples for analysis were collected at Shoreham Harbour, UK, and immediately stored in sealed anoxic jars in the presence of AnaeroGen ${ }^{\mathrm{TM}}$ oxygen-scavenger sachets in order to minimise atmospheric exposure. Samples of corrosion (MIC), bed sediment (SED) and water (WAT) were taken from the "DB", a tidal location inside the port, and from the "BT", a non-tidal location inside the port. Additional samples where obtained from dredged sediment in the main harbour channel.

\section{Mineralogical analyses}

Samples were imaged and analysed using a Zeiss EVO LS 15 SEM equipped with an Oxford Instruments XMax 80 EDX spectrometer, using an accelerating voltage of $10 \mathrm{kV}$ and a beam current of $707 \mathrm{pA}$. In order to avoid destruction of microbes and associated structures under vacuum, and the production of artefacts through carbon coating, the samples were observed uncoated at low vacuum. The samples had not been previously dried and the saturation with seawater to was sufficient to render the samples conductive and avoid the effects of charge accumulation on the sample surface. In order to further reduce the effects of surface electronic charge the samples were observed in backscattered electron mode rather than using secondary electrons.

Blister samples were analysed by XRD in order to characterise the crystalline mineral phases present. Samples were analysed on a Panalytical X'Pert Pro X-ray diffractometer using 2-5 g hand ground sample mounted unbound in to a deep well powder mount. Samples were irradiated using $\mathrm{Cu} \mathrm{Ka}$ radiation generated at $40 \mathrm{kV}$ and $40 \mathrm{nA}$ over a $10 \mathrm{~mm}$ analytical length, using a rotating stage (in order to maximise random orientation). Diffracted X-rays were counted using $10 \mathrm{~s}$ count times at $0.08^{\circ}$ intervals with a nickel filter in place on the diffracted beam path between 5 and $70^{\circ}$ $2 \theta$. Iron X-ray fluorescence under $\mathrm{Cu} \mathrm{Ka}$ radiation resulted in high background to X-ray peaks and low relative peak intensities. The pulse height discrimination (PHD) window of the X-ray detector was adjusted to $45-100 \%$ in order to gain the best possible signal. Phases were identified from diffraction peaks using the HighScore plus software package and the Powder Data File 2012.

Fourier transform infrared spectroscopic (FTIR) measurements were performed using a Perkin Elmer, Spectrum 65 spectrometer, fitted with an attenuated total reflectance (ATR) accessory employing a ZnSe crystal. Measurements through the ATR accessory require good contact between the sample and the ZnSe crystal. This was achieved by uniform, light, manual compaction. The samples were measured in the spectral range $4000-600 \mathrm{~cm}^{-1}$ at a resolution of $4 \mathrm{~cm}^{-1}$. Each spectrum was collected from 16 scans. The data were analysed using PeakFit (Jandel, Scientific Software) in order to convert data from tranmission to absorbance mode, and to allow deconvolution of absorbance peaks. Analysis was focussed in the range $650-1600 \mathrm{~cm}^{-1}$.

XPS depth profile measurements were conducted using an ESCALAB 250xi X-ray photoelectron spectrometer (Thermo Scientific, UK) with a 
MAGCIS $^{\text {TM }}$ Dual Beam lon Source. XPS analysis was carried out using selected area analysis mode with a nominal width of analysis of $400 \mu \mathrm{m}$ and monochromated Al Ka X-rays at $1486.6 \mathrm{eV}$. The MAGCIS source can generate both traditional monatomic ion beams for profiling inorganic materials and also cluster ions for organic layer profiling. In this case of depth profiling corroded iron/steel samples, the gun was selected in monoatomic mode with $3 \mathrm{keV}$ ion energy and raster size $1.2 \mathrm{~mm}$. Sputtering cycle was kept at $120 \mathrm{~s}$ each time with a total of 100 levels for the depth profile analysis. The charge neutraliser and X-ray source were only used during the acquisition of spectra, both being turned off during the sputtering cycle. Survey (wide) scans (step size $1 \mathrm{eV}$, pass energy $150 \mathrm{eV}$, dwell time $50 \mathrm{~ms}$, number of scans 2) and narrow scans (step size $0.1 \mathrm{eV}$, pass energy $20 \mathrm{eV}$, dwell time $100 \mathrm{~ms}$, number of scans 3) of the Fe $2 p$ (binding energy, $\mathrm{BE} \sim 708 \mathrm{eV}), \mathrm{C} 1 \mathrm{~s}(\mathrm{BE} \sim 285 \mathrm{eV}), \mathrm{O} 1 \mathrm{~s}(\mathrm{BE} \sim 531 \mathrm{eV}), \mathrm{N}$ is $(\mathrm{BE} \sim 399 \mathrm{eV}), \mathrm{Mg} 1 \mathrm{~s}(\mathrm{BE} \sim 1304 \mathrm{eV}), \mathrm{S} 2 p(\mathrm{BE} \sim 164 \mathrm{eV})$ and Si $2 p(\mathrm{BE} \sim$ $100 \mathrm{eV})$ ) regions were acquired. Data analyses were carried out using Thermo Avantage software version 5.952.Chemical peak shift due to the sample charging under X-rays and corresponding charge neutralisation, was calculated using $\mathrm{C} 1 \mathrm{~s}$ hydrocarbon peak at $285.0 \mathrm{eV}$ following standard practice. However, during sputtering, where carbon was not present, the metallic Fe $2 p$ binding energy of $707.95 \mathrm{eV}$ was used as a reference point. Where multiple compounds have similar chemical shift reported in the literature, peaks were assigned to the corresponding $\mathrm{Fe}-\mathrm{S}$ phase identified form the $\mathrm{S} 2 p$ spectrum. Full width half maximum (FWHM) peak values of $\mathrm{Fe}$ $2 p$ spectra were allowed to vary between 1.4 and $1.9 \mathrm{eV}$; and for $\mathrm{S} 2 p_{3 / 2}$, they were constrained to vary between 1.1 and $1.6 \mathrm{eV}$. There is a possibility that redox reactions could be induced in the sample as it is sputtered with a monoatomic argon beam for depth profiling. In order to eliminate this possibility a powder sample of reagent grade hydrated ferric sulfate $\left(\mathrm{Fe}_{2}\left(\mathrm{SO}_{4}\right)_{3} \cdot 2 \mathrm{H}_{2} \mathrm{O}\right)$ was first dried at $55^{\circ} \mathrm{C}$, and then analysed to check for iron and sulfur reduction on argon ion sputtering. No effects on the XPS spectra where observed during this process, and the results of analysis of corrosion materials are therefore inferred to be robust (Supplementary Fig. 2).

\section{DNA extraction}

Genomic DNA was extracted from sediment, seawater and corrosion deposit samples. Briefly, $0.25 \mathrm{~g}$ of samples of the sediment and the corrosion blisters were extracted using the optimised Power Soil DNA Isolation kit (MoBio Laboratories) methods described by. ${ }^{51}$ For the seawater, five hundred millilitres were filtered through a $0.45 \mu \mathrm{m}$ filter (Millipore) to retain the bacteria and the content of the filter was extracted using the PowerWater DNA isolation kit (MoBio Laboratories). The DNA quantity and quality of all samples were examined using a Nanodrop Lite spectrophotometer (ThermoScientific). A DNA sample was considered viable for down-stream processing when concentration exceeded $8.5 \mathrm{ng}$ $\mu^{-1}$ and 260/280 ratio was between 1.5 and 1.9 , as recommended by. ${ }^{52}$ All extracted genomic DNA samples were stored at $-80^{\circ} \mathrm{C}$ until further processing.

\section{6s RNA}

$16 \mathrm{~S}$ metagenomic analysis was used for species profiling and species determination on the samples used to validate other techniques (two MIC samples, two seawater samples, two sediment samples). MiSeq nextgeneration sequencing NGS (V1-V3 region) with the $2 \times 300$ bp paired-end read module was performed by Eurofins Genomics. Taxonomical assignment and read abundance estimation of all OTUs were done to species level.

\section{GeoChip $^{\mathrm{TM}}$ hybridisation and analysis}

DNA extracted from the samples was processed at the Institute for Environmental Genomics (IEG) at the University of Oklahoma as previously described. ${ }^{53}$ Purified DNA $(1 \mu \mathrm{g})$ was labelled with Cy5, purified and hybridised at $42^{\circ} \mathrm{C}$ for $16 \mathrm{~h}$ with the GeoChip ${ }^{\mathrm{TM}} 5.0$ on a MAUl hybridisation station (BioMicro, USA). After hybridisation, microarrays were scanned using a microarray scanner and the intensity of each spot was determined. Raw data were submitted to Microarray Data Manager software, designed at IEG (http://ieg.ou.edu/microarray/) and analysed using the data analysis pipeline. To call probes positive, we used a floating signal-to-noise ratio (SNR) so that the hyperthermophile probes accounted for $5 \%$ of the positive signals. The probes were assigned as negative if the signal was $<1.3$ times the background. The signal intensity was then normalised by dividing the signal intensity of each spot by the mean intensity of the microarray. The normalised data were then analysed using the Microarray
Data Manager. Alpha-diversity was calculated using Shannon-Wiener index $(H)$, Simpson index $(1 / D)$ and Simpson evenness $(E)$. The overlapping genes between all samples were calculated by dividing the number of overlapping genes by the number of genes present in both samples.

\section{DATA AVAILABILITY}

The datasets generated during and/or analysed during the current study are available in summary form in the supplementary material and are available from the corresponding author on reasonable request. Full processed microarray and 16sRNA datasets are available at https://doi.org/10.5061/dryad.52vq8t5 hosted by http:// datadryad.org/. Raw metagenomic data are available at ArrayExpress (https://www. ebi.ac.uk/arrayexpress/), accession numbers E-MTAB-8364 for GeoChip Microarray data, and E-MTAB-8373 for 16sRNA data.

Received: 3 June 2019; Accepted: 30 September 2019; Published online: 25 October 2019

\section{REFERENCES}

1. Cheung, C. W., Walsh, F. C., Campbell, S. A., Chao, W. T. \& Beech, I. B. Microbial contributions to the marine corrosion of steel piling. Int. Biodeterior. Biodegredation 34, 259-274 (1994).

2. Breakel, J. E., \& Siegwart, M. Management of accelerated low water corrosion in steel maritime structures. Report C634 Construction Industry Research and Information Association (2005).

3. Beech, I. B. \& Campbell, S. A. Accelerated low water corrosion of carbon steel in the presence of a biofilm harbouring sulphate-reducing and sulphur-oxidising bacteria recovered from a marine sediment. Electrochim. Acta 54, 14-21 (2008).

4. Dzierzewicz, B., Cwalina, B., Chodurek, E. \& Wilczok, T. The relationship between microbial metabolic activity and biocorrosion of carbon steel. Res. Microbiol. 148, 785-793 (1997).

5. Gubner, R. Biofilms and accelerated low-water corrosion of carbon steel piling in tidal waters. Ph.D. Thesis, University of Portsmouth (1998).

6. Dinh, H. T. et al. Iron corrosion by novel anaerobic microorganisms. Nature 427, 829-832 (2004).

7. Ilhan-Sungur, E., Cansever, N. \& Cotuk, A. Microbial corrosion of galvanized steel by a freshwater strain of sulphate reducing bacteria (Desulfovibrio sp.). Corros. Sci. 49, 1097-1109 (2007).

8. Païssé, S. et al. Sulfate-reducing bacteria inhabiting natural corrosion deposits from marine steel structures. Appl. Microbiol. Biotechnol. 97, 7493-7504 (2012).

9. Stipanicev, M. et al. Corrosion behaviour of carbon steel in presence of sulfatereducing bacteria in seawater environment. Electrochim. Acta 113, 390-406 (2013).

10. Marty, F. et al. Identification of key factors in accelerated low water corrosion through experimental simulation of tidal conditions: influence of stimulated indigenous microbiota. Biofouling: J. Bioadhesion Biofilm Res. 28, 363-380 (2014).

11. Little, B. J., Ray, R. I. \& Pope, R. K. Relationship between corrosion and the biological sulfur cycle: a review. Corrosion 56, 433-443 (2000).

12. Dall'Agnol, L. T. \& Moura, J. J. G. in Understanding Biocorrosion: Fundamentals and Applications (eds Liengen, T., Feron, D., Basseguy, R. \& Beech, I. B.) 77-106 (Woodhead Publishing Ltd., 2015).

13. Melchers, R. E. Influence of dissolved inorganic nitrogen on accelerated low water corrosion of marine steel piling. Corrosion 69, 95-103 (2013).

14. Jeffries, R. \& Melchers, R. E. Corrosion of vertical mild steel strips in seawater. Corros. Sci. 51, 2291-2297 (2009).

15. Malard, E. et al. Microbiologically induced corrosion of steel structures in port environment: improving prediction and diagnosis of ALWC (MICSIPE). EUR 25904 EN. European Commission, Directorate-General for Research and Innovation, https://doi.org/10.2777/93930 (2013).

16. Madigan, M. T., Martinko, J. M., Dunlap, P. V. \& Clark, D. P. Biology of Microorganisms (Pearson Benjamin Cummings, San Francisco, CA, 2009).

17. Melchers, R. E. \& Jeffrey, R. Corrosion of long vertical steel strips in the marine tidal zone and implications for ALWC. Corros. Sci. 65, 26-36 (2012).

18. Kakooei, S., Ismail, M. C. \& Ariwahjoedi, B. Mechanisms of microbiologically influenced. Corros.: A Rev. World Appl. Sci. J. 17, 524-531 (2012).

19. Enning, D. \& Garrelfs, J. Corrosion of iron by sulfate-reducing bacteria: new views of an old problem. Appl. Environ. Microbiol. 80, 1226-1236 (2014).

20. Xu, N., Wang, F., Lv, M. \& Lu, C. Microarray expression profile analysis of long noncoding RNAs in human breast cancer: a study of Chinese women. Biomedicine Pharmacother. 69, 221-227 (2015).

21. Tu, Q. et al. GeoChip 4: a functional gene-array-based high-throughput environmental technology for microbial community analysis. Mol. Ecol. Resour. 14, 914-928 (2014). 
22. Atlas, R. M. \& Bartha, R. Microbial Ecology: fundamentals and applications (t. Edition Ed.). (Benjamin/Cummings Science Publishing, California, USA, 1998).

23. Rappe, M. S. \& Giovannoni, S. J. The uncultured microbial majority. Annu. Rev. Microbiol. 57, 369-394 (2003).

24. Whitman, W. B., Coleman, D. C. \& Wiebe, W. J. Prokaryote: the unseen majority. Proc. Natl Acad. Sci., USA 95, 6578-6583 (1998).

25. Jeffrey, R. \& Melchers, R. E. Bacteriological influence in the development of iron sulphide species in marine immersion environments. Corros. Sci. 45, 693-714 (2003).

26. Guilbaud, R., White, M. L. \& Poulton, S. W. Surface charge and growth of sulphate and carbonate green rust in aqueous media. Geochim. Cosmochim. Acta 108, 141-153 (2013).

27. Seyeus, A., Zanna, S., \& Marcus, P. in Understanding Biocorrosion: Fundamentals and Applications (eds Liengen, T., Feron, D., Basseguy, R. \& Beech, I. B.) 197-212 (Woodhead Publishing Ltd., 2015).

28. Meyer, B. \& Kuever, J. Molecular analysis of the diversity of sulfate-reducing and sulfur-oxidizing prokaryotes in the environment, using aprA as functional marker gene. Appl. Environ. Microbiol. 73, 7664-7679 (2007).

29. Niu, J. et al. The shift of microbial communities and their roles in sulfur and iron cycling in a copper ore bioleaching system. Sci. Rep. 6, 1-7 (2016).

30. Wagner, M. A., Roger, A. J., Flax, J. L., Brusseau, G. A. \& Stahl, D. A. Phylogeny of dissimilatory sulfite reductases supports and early origin of sulfate respiration. $J$. Bacteriol. 180, 2975-2982 (1998).

31. Pineau., S. et al. Formation of Fe (II-III) hydroxysulphate green rust during marine corrosion of steel associated to molecular detection of dissimilatory sulphitereductase. Corros. Sci. 25, 1099-1111 (2008).

32. Ni, G. et al. Haloalkaliphilic microorganisms assist sulfide removal in a microbial electrolysis cell. J. Hazard. Mater. 363, 197-204 (2019).

33. Tan, W., Huang, C., Chen, C., Liang, B. \& Wang, A. Bioaugmentation of activated sludge with elemental sulfur producing strain Thiopseudomonas denitrificans X2 against nitrate shock load. Bioresour. Technol. 220, 647-650 (2016).

34. Gomez-Alvarez, V., Revette, R. P., \& Santo Domingo, J. W. Metagenome analyses of corroded concrete wasterwater pipe biofilms reveal a complex microbial system. BMC Microbiol. 12, https://doi.org/10.1186/1471-2180-12-122 (2012).

35. Pham, V. H. et al. Molecular analysis of the diversity of the sulfide: quinone reductase (sqr) gene in sediment environments. Microbiology 154, 3112-3121 (2008).

36. Anandham, R. et al. Chemolithoautotrophic oxidation of thiosulfate and phylogenetic distribution of sulfur oxidation gene (soxB) in rhizobacteria isolated from crop plants. Res. Mircobiol. 159, 579-589 (2008).

37. Meyer, B., Imhoff, J. F. \& Kuever, J. Molecular analysis of the distribution and phylogeny of the sox $B$ gene among sulfur-oxidizing bacteria - evolution of the Sox sulfur oxidation enzyme system. Environ. Microbiol. 9, 2957-2977 (2007)

38. Petri, R., Podgersek, L. \& Imhoff, J. F. Phylogeny and distribution of the soxB gene among thiosulfate-oxidizing bacteria. FEMS Microbiol. Lett. 197, 171-178 (2001).

39. Hansel, C. M., Ferdelman, T. G. \& Tebo, B. M. Among biogeochemical cycles: novel insights from reactive intermediates. Elements 11, 409-414 (2015).

40. Javaherdashti, R. Microbiological contribution to accelerated low water corrosion of support piles. Port. Technol. 29, 59-63 (2006).

41. Rimstidt, J. D. \& Vaughan, D. J. Pyrite oxidation: a state-of-the-art assessment of the reaction mechanism. Geochimica et. Cosmochimica Acta 67, 873-880 (2003).

42. Weerasooriyaa, R., Makehelwala, M. \& Bandara, A. Probing reactivity sites on pyrite-oxidative interactions with 4-chlorophenol. Colloids Surf. A: Physicochem. Eng. Asp. 367, 65-69 (2010).

43. Lu, X. \& Wang, H. Microbial oxidation of sulfide tailings and the environmental consequences. Elements 8, 119-124 (2012).

44. Bermont-Louis, D., Janvier, M., Grimont, P. A. D., Dupont, I. \& Vallaeys, T. Both sulfate-reducing bacteria and Enterobacteriaceae take part in marine biocorrosion of carbon steel. J. Appl. Microbiol. 102, 161-168 (2007).

45. Boudaud, N., Coton, M. E., Pineau, S., Travert, J. \& Amiel, C. Biodiversity analysis by polyphasic study of marine bacteria associated with biocorrosion phenomena. J. Appl. Microbiol. 109, 166-179 (2009).

46. Muller, A. L., Kjeldsen, K. U., Rattei, T., Pester, M. \& Loy, A. Phylogenetic and environmental diversity of DsrAB-type dissimilatory (bi)sulfite reductases. ISME J. 9, 1152-1165 (2014).

47. Melchers, R. E., Jeffrey, R. \& Usher, K. M. Localized corrosion of steel sheet piling. Corros. Sci. 79, 139-147 (2014).

48. Beech, I. B., Sunner, J. A. \& Hiraoka, K. Microbe-surface interactions in biofouling and biocorrosion processes. Int. Microbiol. 8, 157-168 (2005).

49. Melchers, R. E. \& Jeffery, R. The critical involvement of anaerobic bacterial activity in modelling the corrosion of mild steel in marine environments. Electrochim. Acta 54, 80-85 (2008).

50. Little, B. J., Ray, R. I., Lee, J. S. in Understanding Biocorrosion: Fundamentals and Applications (eds Liengen, T., Feron, D., Basseguy, R. and Beech, I. B. eds.) 239-240 (Woodhead Publishing Ltd., 2015).
51. Marty, F. et al. Evaluation and optimization of nucleic acid extraction methods for the molecular analysis of bacterial communities associated with corroded carbon steel. Biofouling 28, 363-380 (2012).

52. Glomics Inc. GeoChip Technology. Retrieved from http://www.glomics.com/gchtech.html (2014).

53. Van Nostrand, J. D., Liang, Y., He, Z., Li, G. \& Zhou, J. in Handbook of Hydrocarbon and Lipid Microbiology (ed Timmis, K. N.) 2677-2685 (Springer, Berlin, Heidelberg, 2010). https://doi.org/10.1007/978-3-540-77587-4_198.

54. Alcántara, J. et al. An attempt to classify the morphologies presented by different rust phases formed during the exposure of carbon steel to marine atmospheres. Mater. Charact. 118, 65-78 (2016).

\section{ACKNOWLEDGEMENTS}

This study was funded by ArcelorMittal S.A., Luxembourg. The authors would like to thank Tony Parker of Shoreham Port Authority for access and logistical support. X-ray photoelectron spectroscopy was carried out on the XPS-FOAM facility which is jointly funded by NERC (RCUK) and the University of Brighton.

\section{AUTHOR CONTRIBUTIONS}

M.S. led the writing of this manuscript, undertook SEM examination of samples, contributed to interpretation of FTIR and XPS spectra and lead the overall data interpretation. M.B. contributed to microbial DNA extraction, the interpretation of microarray data and the writing of the manuscript. R.B. undertook sampling and contributed to FTIR analyses and interpretation, microbial DNA extraction, the interpretation of microarray data and the writing of the manuscript. This work is linked to R.B.'s doctoral studies. H.B. conceived and led the original project, contributed engineering and environmental context and contributed to the writing of the manuscript. J.C. led the microbial aspects of the study, and contributed to the design of microbial DNA extraction, the interpretation of microarray data and the writing of the manuscript. S.R. completed XPS data acquisition and data interpretation and contributed to the writing of the manuscript. T.U. contributed to the design and implementation of the original project, the overall data interpretation and the writing of the manuscript.

\section{COMPETING INTERESTS}

The Authors declare no Competing Non-Financial Interests but the following Competing Financial Interests: This work was funded by ArcelorMittal S.A. TU is an employee of ArcelorMittal and was involved in the conceptualisation of the original project and in the preparation of the manuscript. ArcelorMittal will not gain or lose financially through the publication of this manuscript.

\section{ADDITIONAL INFORMATION}

Supplementary information is available for this paper at https://doi.org/10.1038/ s41529-019-0099-9.

Correspondence and requests for materials should be addressed to M.S.

Reprints and permission information is available at http://www.nature.com/ reprints

Publisher's note Springer Nature remains neutral with regard to jurisdictional claims in published maps and institutional affiliations.

Open Access This article is licensed under a Creative Commons Attribution 4.0 International License, which permits use, sharing, adaptation, distribution and reproduction in any medium or format, as long as you give appropriate credit to the original author(s) and the source, provide a link to the Creative Commons license, and indicate if changes were made. The images or other third party material in this article are included in the article's Creative Commons license, unless indicated otherwise in a credit line to the material. If material is not included in the article's Creative Commons license and your intended use is not permitted by statutory regulation or exceeds the permitted use, you will need to obtain permission directly from the copyright holder. To view a copy of this license, visit http://creativecommons. org/licenses/by/4.0/.

(c) The Author(s) 2019 